Van de Walle, S. (2008). Perceptions of corruption as distrust? Cause and effect in attitudes towards government. In: Huberts, L., Jurkiewicz, C., \& Maesschalck, J. (eds.). Ethics and integrity and the politics of governance. Cheltenham: Edward Elgar, pp. 215-236.

\title{
PERCEPTIONS OF CORRUPTION AS DISTRUST? CAUSE AND EFFECT IN ATTITUDES TOWARDS GOVERNMENT.
}

\author{
Steven Van de Walle
}

\section{Introduction}

A foreigner moves to Belgium, and needs a telephone line in his new apartment. His Belgian friends wish him good luck, telling him it will take months, unless he has some connections in the public telephone company, or knows a politician who could intervene for him. The foreigner, not being well-connected, reluctantly decides to follow the standard procedure, and visits the telephone company's office the next day. To his surprise, he is the only customer there and is able to file his application within 20 minutes, helped by a very friendly employee. One day later, his telephone is connected. His friends are amazed. Pleasantly surprised about this fast service, he goes back to the telephone company's office, taking a bottle of his native country's wine for the friendly and helpful employee, and asked the employee how comes his telephone was connected that fast, while everyone told him it would take months. The employee smiles and tells him, 'well, you know, you were the first customer in weeks following the normal procedure, and not having some local politician call us. We really appreciated that, and decided to connect your telephone right away’.

This joke, emergent from the 1980s, illustrates how political and other ‘connections' have been a central element in the functioning of public services in Belgium. Belgium has had an image of being a corrupt country for a long time 
(Maesschalck, 2002; De Winter, 2003). A number of high-profile corruption scandals in the 1980s and 1990s has contributed to this image, and the structure of the party-political system has been a major factor in some of these cases (De Winter, 2000). Recently, however, there appears to have been a positive evolution (Van de Walle, 2004b).

In this chapter, we use a representative survey of 3168 Flemish citizens to analyze the determinants of perceptions of administrative and political corruption. We will show that citizens' perceptions of corruption are embedded in general attitudes towards government and that subjective corruption indicators may be heavily influenced by predispositions towards government, and therefore do not reflect the respondents' personal experience with corruption. Because many citizens do not have frequent personal experience with corrupt practices, the answer they give in surveys is influenced by other factors. The absence of an experiential basis allows respondents considerable freedom to take certain other attitudinal aspects into account. This creates problems of comparability and invites respondents to broaden their frame of reference to whatever factor they wish when giving an opinion on corruption. Perceptions of administrative corruption, hence, both contribute to the general attitudes towards the administration and government as well as being a consequence of them (Van de Walle, 2004c).

In the first section we briefly present some of the available survey material on citizens' perception of public sector corruption in Belgium. Using data from a general survey administered in Flanders (Northern part of Belgium) in 2003, we subsequently analyze determinants of general perceptions of corruption and unethical behavior. We show that these perceptions are to a large extent influenced by feelings of political alienation and general attitudes towards government. It is therefore difficult to distinguish cause and effect between trust in government and perceptions of corruption. We then will show that general perceptions of corruption should not be seen as an expression of individual experience. Parallels become 
apparent with how citizens evaluate government services, where a disconnection seems to exist between generally positive personal bureaucratic encounters and more negative attitudes towards public services in general. We end by reviewing possibilities for avoiding 'contamination' of perceptions of corruption by general attitudes towards government, and for developing indicators that better measure actual corruption.

\section{Perceived corruption in Belgium}

By means of an introduction, we briefly present some of the available survey data on citizens' perception of corruption in Belgium. The 1995 ISPO General Election Study (Beerten, Billiet, Carton, \& Swyngedouw, 1997) revealed that 29 percent of Belgians thought politicians to be more corrupt than other individuals, while 65.5 percent did not see a difference. This study also revealed that citizens have more problems with politicians who demand bribes or payments for granting government contracts than with politicians who accept money for a contract. A politician using bribes for funding his or her personal election campaign is considered more reprehensible than is a politician who transfers the money to his or her political party, although 73.9 percent of respondents overall viewed accepting bribes as unacceptable ${ }^{1}$.

The best-known source for corruption indicators is the Transparency International (TI) Corruption Perceptions Index (CPI). This index ranks countries

\footnotetext{
1 'Hardly acceptable' and 'never acceptable'. Of the remaining respondents, 17.8 per cent stated this is 'sometimes acceptable', and 5.4 per cent stated that accepting money and giving it to one’s party is 'completely acceptable'.
} 
based on perceived corruption among politicians and public officials ${ }^{2}$. Even though the CPI does not lend itself to making time-series comparisons, the trend for Belgium in recent years is quite clear: Since 1999 there has been an unambiguous positive trend (the lower the score, the higher perceived corruption). The score does not return to 1980s level, but this is probably due to changes in the method of measurement and the fact that data for Belgium and Luxembourg have not always been disaggregated. Luxembourg generally ranks higher than Belgium.

\section{Figure 1: Belgium in the Corruption Perceptions Index}

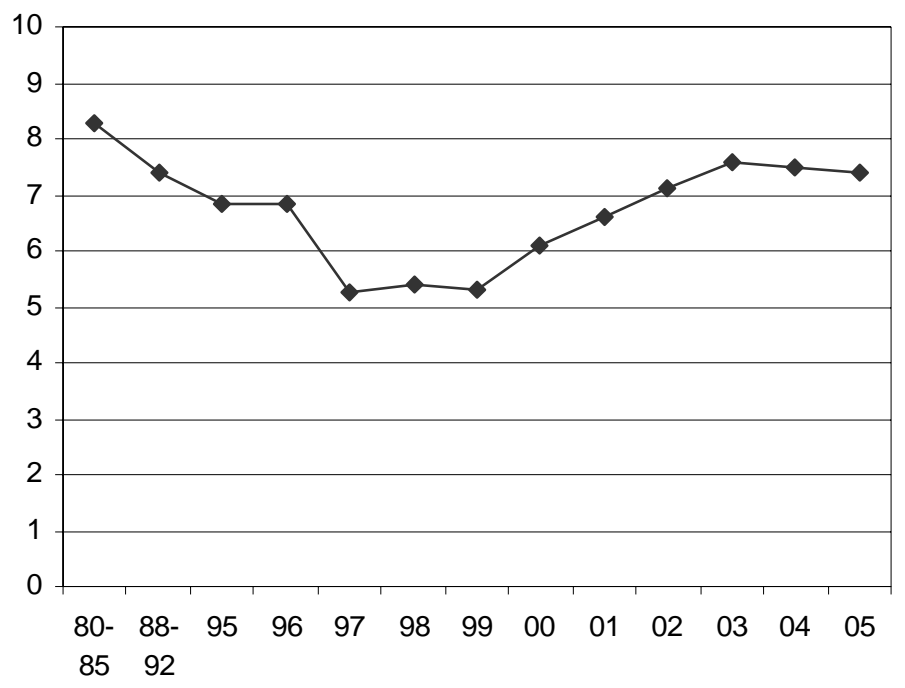

\section{Source: Transparency International: Corruption Perceptions Index}

In 2005, Belgium ranked $19^{\text {th }}$ among the least corrupt countries (in a total of 133 countries). This puts the country on a par with Ireland and higher than, for example, Spain and Japan. Still, Belgium performs worse than many other EU15 countries, including its neighboring countries. Compared to 2004, the country declined in the rankings, even though this change is probably not large enough to be significant.

Additional information on Belgian citizens' attitude towards corruption can be

\footnotetext{
${ }^{2}$ www.transparency.org, note that CPI scores cannot just be compared on a yearto-year basis, as composition has changed a number of times.
} 
found in the 1999-2000 European Values Study. One question was about the perceived occurrence of taking bribes. Table 1 shows the answers in a series of European countries and indicates significant differences between countries. In Belgium, 27.8 percent of the respondents report that almost all or many of their compatriots accept bribes. This percentage is comparable to that in Austria, Germany and the UK, yet higher than that found in Finland or Luxemburg. In Italy, however, this percentage peaks at 41.2 per cent.

Table 1: According to you, how many of your compatriots do the following? Accepting a bribe in the course of their duties?

\begin{tabular}{|l|l|l|l|l|}
\hline$\%$ & almost all & Many & some & almost none \\
\hline BE & 4.8 & 23.0 & 63.5 & 8.7 \\
\hline AT & 2.4 & 30.4 & 63.3 & 3.9 \\
\hline DE & 5.1 & 27.9 & 61.2 & 5.8 \\
\hline FI & 2.3 & 20.3 & 64.5 & 13.0 \\
\hline IT & 7.4 & 43.8 & 46.5 & 2.3 \\
\hline LU & 0.9 & 9.7 & 38.1 & 33.0 \\
\hline UK & 1.8 & 29.4 & 60.0 & 8.7 \\
\hline
\end{tabular}

Source: European Values Study, only results for EU15 countries (Halman, 2001)

Another question asked to what extent citizens considered it justified for someone to accept a bribe in the course of his or her duties. The percentage of respondents that considered accepting a bribe to never be justified was 77.7 percent in 1981, 78.6 in 1990, and 84.1 percent in 1999. Figure 2 illustrates how the Transparency International and European Values Study findings are related. 
Figure 2: Perceptions of corruption (TI) and justifiability of accepting bribes (EVS) in the EU-countries

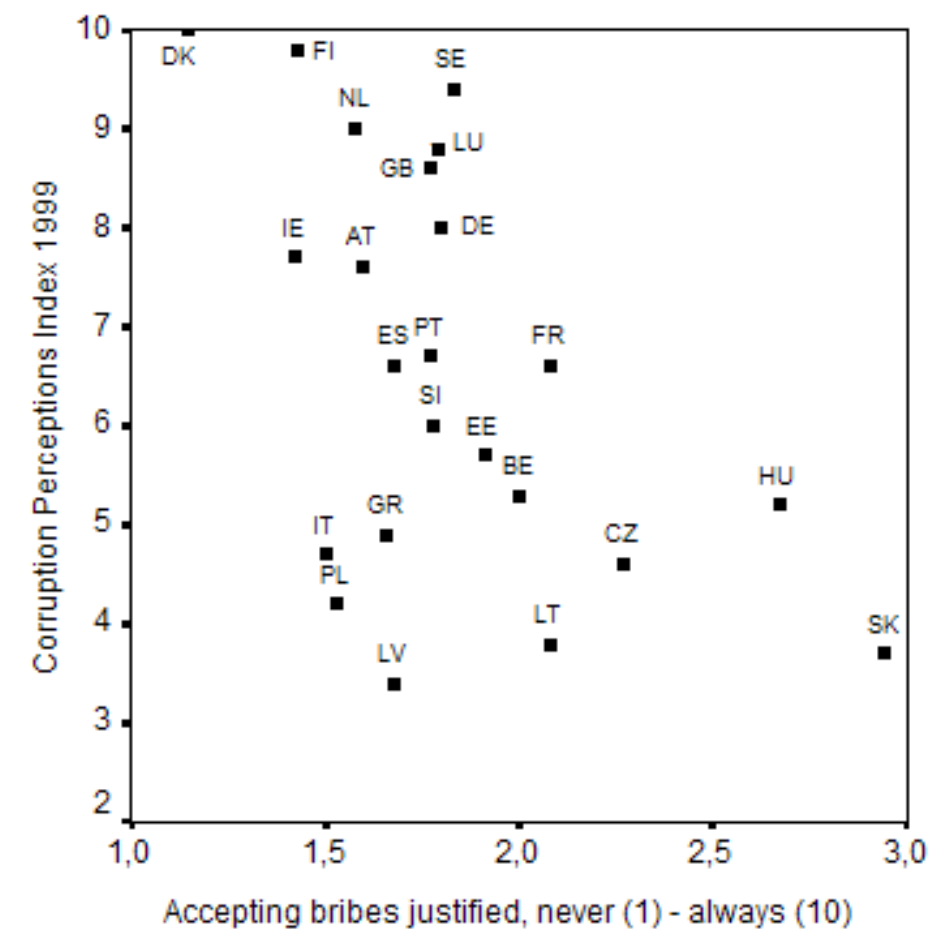

Source: Transparency International Corruption Perceptions Index 1999, where ' 10 ' means that corruption is perceived to be very low; European Values Study (1999-2000 wave). 'Please tell me for each of the following statements whether you think it can always be justified, never be justified, or something in between. Someone accepting a bribe in the course of their duties.' Scale 1 (never) to 10 (always), mean score (Halman, 2001)

Considering bribes to be unjustified does not lead to perceptions of corruption to be lower in a particular country, though there are exceptions. Perceptions regarding accepting bribes is actually quite similar across most countries, despite differences in CPI scores. In only a few Central-European countries is accepting bribes considered to be somewhat more justified, yet the differences remain small. 


\section{What determines perceptions of corruption? An analysis}

For this section, we use data from the Werken aan de Overheid survey (WADOWorking on Government), which was administered as part of a research project commissioned by the ministry of the Flemish Community (2000-2004, www.kuleuven.be/trust). The questionnaire dealt with citizens' attitudes towards the public sector and contained items on socio-demographics, citizens and public services, citizens and politics, and citizens and society. Participants were inhabitants of the Flemish Region (aged 18-85). Three surveys were administered: a face-to-face survey (2002, $\mathrm{n}=1248$, response rate 68.2 percent), an initial mail survey (2002, $n=2166$, response rate 63.5 percent), and a second mail survey (2003, $n=3168$, response rate 61.9 percent $^{3}$ ). We will only report data from the 2003 survey here (Van de Walle, Kampen, Maddens, \& Bouckaert, 2004). Questionnaires were sent with two-week intervals. Fifteen successive waves covered a period of half a year (third and fourth quarters of 2003). In this way the impact of events on citizens' opinions could be measured and long-term impacts and evolutions analyzed. We do not, however, analyze trends in this chapter. Respondents each received three mailings: an introductory letter, the questionnaire with postage-paid return envelope and a reminder. As an incentive, a limited number of gifts (approx. 0.5 to 1 percent of respondents) was given to respondents by means of a lottery.

The survey contained a number of issues related to corruption and favoritism, five of which are analyzed here in greater detail. Three of these articulate corruption-related issues, the other two focus on issues of equal treatment.

\footnotetext{
${ }^{3}$ In the 2003 survey, 25-44 aged are underrepresented, 45-60 aged tended to return the questionnaire more often, and the +70 category is again underrepresented. Response was higher in rural areas.
} 
Table 2: Perceptions of unethical behavior in the public sector in Flanders

\begin{tabular}{|c|c|c|c|c|c|}
\hline$\%$ & $\begin{array}{l}\text { totally } \\
\text { disagree }\end{array}$ & disagree & $\begin{array}{l}\text { not agree, not } \\
\text { disagree }\end{array}$ & agree & totally \\
\hline $\begin{array}{l}\text { Civil servants are more } \\
\text { corrupt than other people }\end{array}$ & 8.4 & 28.7 & 38.2 & 19.0 & 5.7 \\
\hline $\begin{array}{l}\text { Politicians are more corrupt } \\
\text { than other people }\end{array}$ & & 18.4 & 36.2 & 29.4 & 13.1 \\
\hline $\begin{array}{l}\text { You need 'connections' to } \\
\text { get something done by } \\
\text { government or the public } \\
\text { administration }\end{array}$ & 2.1 & 11.3 & 30.5 & 40.5 & 15.7 \\
\hline $\begin{array}{l}\text { All users of public services } \\
\text { are treated equally }\end{array}$ & 10.9 & 40.2 & 26.1 & 16.7 & 6.1 \\
\hline $\begin{array}{l}\text { Users of public services } \\
\text { always get what they're } \\
\text { entitled to }\end{array}$ & 7.8 & 35.4 & 35.5 & 18.6 & 2.7 \\
\hline
\end{tabular}

Source: Werken aan de Overheid (WADO) 2003, n=3168.

Surprisingly, 56.2 percent of the respondents believe an individual needs connections to get something done from government or public administrators; only 13.3 percent disagree. The results are somewhat more encouraging in response to the question regarding corruption: just under a quarter of respondents believe that civil servants are more corrupt than other people. Politicians, however, are perceived to be more corrupt than other people by 42.4 percent of participants in the survey. Responses to these three questions are strongly correlated. 
Table 3: Perceived ethical treatment of citizens, correlations

\begin{tabular}{|l|l|l|l|l|}
\hline & $\begin{array}{l}\text { users get } \\
\text { what } \\
\text { entitled to }\end{array}$ & $\begin{array}{l}\text { civil } \\
\text { servants } \\
\text { corrupt }\end{array}$ & $\begin{array}{l}\text { need } \\
\text { connections }\end{array}$ & $\begin{array}{l}\text { politicians } \\
\text { corrupt }\end{array}$ \\
\hline users treated equally & $0.51^{* *}$ & $-0.08^{* *}$ & $-0.17^{* *}$ & $-0.13^{* *}$ \\
\hline $\begin{array}{l}\text { users get what entitled } \\
\text { to }\end{array}$ & & $-0,07^{* *}$ & $-0.16^{* *}$ & $-0.11^{* *}$ \\
\hline civil servants corrupt & & & $0.43^{* *}$ & $0.40^{* *}$ \\
\hline need connections & & & & $0.36^{* *}$ \\
\hline
\end{tabular}

**Correlation is significant at the 0.01 level; Kendall's tau_b

The correlation table along with a factor analysis confirm that the items are measuring different dimensions of ethical treatment. While opinions on corruption are quite moderate, there is evidently something wrong with equal treatment. Just one out of five respondents agrees that users of public services are treated equally and get what they're entitled to, while over half of the respondents disagree.

In the next step, we attempt to explain these attitudes by socio-demographic characteristics, social attitudes, voting behavior, and media exposure. Sociodemographic variables are gender, level of education (six levels), and age (six categories from 18-24 to $65^{+}$). Social attitudes are individualism (based on two items: 'Humanity, brotherhood and solidarity are all nonsense. Everybody has to take care of themselves first and defend their own interests' and 'People should always pursue their personal pleasure, and shouldn't think too much about others'), and authoritarianism (also based on two items: 'Obedience and respect for authority are the two most important virtues children have to learn' and 'What we need is strong leaders who tell us what to do'). Voting behavior is based on the question 'Suppose there are national elections next Sunday. Which would be your preferred political party?’ This variable has been recoded into seven dummies, each referring to one of the main parties; AGALEV (greens), CD\&V (Christiandemocrats), N-VA (Flemish nationalists), SP-A (social democrats), Spirit (Flemish 
nationalist and social democrat), Vlaams Blok (extreme right) and VLD (liberals). The three media variables measure whether an individual reads reputable newspapers, watches the news on public television, and/or watches news on commercial television. The five dependent variables have been recoded into trichotomous variables. Table 4 gives the results of the multivariate ordinal logit regression models.

Table 4: Determinants of perceptions of ethical behavior: ordinal regression models

\begin{tabular}{|c|c|c|c|c|c|}
\hline & $\begin{array}{l}\text { Civil } \\
\text { servants } \\
\text { corrupt }\end{array}$ & $\begin{array}{l}\text { Politicians } \\
\text { corrupt }\end{array}$ & $\begin{array}{l}\text { Need } \\
\text { connectio } \\
\text { ns }\end{array}$ & $\begin{array}{l}\text { All } \\
\text { treated } \\
\text { equally }\end{array}$ & $\begin{array}{l}\text { Get } \\
\text { what } \\
\text { entitled } \\
\text { to }\end{array}$ \\
\hline \multirow[t]{2}{*}{$\begin{array}{l}\text { SEX } \quad(0=\text { male, } \\
1=\text { female })\end{array}$} & 0.185* & 0.050 & 0.21** & $\begin{array}{l}-0.024 \\
\end{array}$ & 0.143* \\
\hline & $(0.074)$ & $(0.074)$ & $(0.077)$ & $(0.074)$ & $(0.073)$ \\
\hline \multirow[t]{2}{*}{ EDUCATION } & $-0.128 * * *$ & $-0.082 *$ & $\begin{array}{l}- \\
0.115 * * *\end{array}$ & -0.020 & $-0.073 *$ \\
\hline & $(0.033)$ & $(0.032)$ & $(0.033)$ & $(0.032)$ & $(0.032)$ \\
\hline \multirow[t]{2}{*}{ AGE } & 0.021 & 0.012 & -0.001 & 0.007 & 0.032 \\
\hline & $(0.027)$ & $(0.027)$ & $(0.028)$ & $(0.027)$ & $(0.027)$ \\
\hline \multirow[t]{2}{*}{$\begin{array}{l}\text { AUTHORITARIA } \\
\text { NISM }\end{array}$} & $0.041 * *$ & 0.025 & $0.038 * *$ & $0.047 * * *$ & $\begin{array}{l}\text { 0.050* } \\
* *\end{array}$ \\
\hline & $(0.014)$ & $(0.014)$ & $(0.014)$ & $(0.014)$ & $(0.014)$ \\
\hline \multirow[t]{2}{*}{$\begin{array}{l}\text { INDIVIDUALIS } \\
\mathrm{M}\end{array}$} & $0.159 * * *$ & $0.142 * * *$ & $0.096 * * *$ & -0.002 & $\begin{array}{l}\text { 0.048* } \\
* *\end{array}$ \\
\hline & $(0.014)$ & $(0.014)$ & $(0.015)$ & $(0.014)$ & $(0.014)$ \\
\hline \multirow[t]{2}{*}{ PARTY: agalev } & 0.041 & -0.027 & $-0.514 *$ & 0.036 & 0.266 \\
\hline & $(0.23)$ & $(0.225)$ & $(0.229)$ & $(0.232)$ & $(0.228)$ \\
\hline \multirow[t]{2}{*}{ PARTY: cd\&v } & $-0.348^{* *}$ & -0.174 & $-0.297 *$ & 0.193 & 0.233 \\
\hline & $(0.132)$ & $(0.132)$ & $(0.139)$ & $(0.133)$ & $(0.131)$ \\
\hline \multirow[t]{2}{*}{ PARTY: n-va } & -0.103 & 0.152 & 0.009 & -0.258 & -0.080 \\
\hline & $(0.213)$ & $(0.213)$ & $(0.221)$ & $(0.223)$ & $(0.215)$ \\
\hline
\end{tabular}




\begin{tabular}{|c|c|c|c|c|c|}
\hline PARTY: sp-a & -0.172 & $-0.475^{* * *}$ & $-0.392 * *$ & $0.373^{* *}$ & $\begin{array}{l}0.343 * \\
*\end{array}$ \\
\hline & $(0.131)$ & $(0.132)$ & $(0.138)$ & $(0.132)$ & $(0.131)$ \\
\hline \multirow[t]{2}{*}{ PARTY: spirit } & 0.356 & -0.128 & 0.174 & 0.201 & 0.361 \\
\hline & $(0.212)$ & $(0.217)$ & $(0.238)$ & $(0.212)$ & $(0.208)$ \\
\hline \multirow{2}{*}{$\begin{array}{l}\text { PARTY: vlaams } \\
\text { blok }\end{array}$} & $0.393^{* *}$ & $0.617 * * *$ & 0.265 & -0.067 & -0.241 \\
\hline & $(0.142)$ & $(0.152)$ & $(0.16)$ & $(0.146)$ & $(0.144)$ \\
\hline \multirow[t]{2}{*}{ PARTY: vld } & -0.188 & $-0.671 * * *$ & -0.238 & 0.115 & 0.167 \\
\hline & $(0.129)$ & $(0.131)$ & $(0.138)$ & $(0.132)$ & $(0.129)$ \\
\hline \multirow{2}{*}{$\begin{array}{l}\text { QUALITY } \\
\text { NEWSPAPERS }\end{array}$} & -0.166 & -0.190 & $-0.240 *$ & 0.009 & -0.098 \\
\hline & (0.108) & (0.105) & $(0.107)$ & $(0.107)$ & $(0.106)$ \\
\hline \multirow{2}{*}{$\begin{array}{l}\text { TV NEWS public } \\
\text { TV }\end{array}$} & -0.137 & 0.019 & -0.233 & 0.185 & -0.064 \\
\hline & $(0.134)$ & $(0.138)$ & $(0.145)$ & (0.135) & (0.133) \\
\hline \multirow{2}{*}{$\begin{array}{l}\text { TV NEWS } \\
\text { commercial TV }\end{array}$} & 0.152 & $0.295^{*}$ & 0.087 & 0.252 & 0.043 \\
\hline & $(0.132)$ & $(0.135)$ & $(0.141)$ & $(0.133)$ & $(0.132)$ \\
\hline $\mathrm{N}$ & 2742 & 2747 & 2749 & 2731 & 2735 \\
\hline $\begin{array}{l}\text { Nagelkerke } \\
\text { pseudo } \mathrm{R}^{2}\end{array}$ & 0.148 & 0.143 & 0.098 & 0.017 & 0.040 \\
\hline
\end{tabular}

Note: standard errors in parenthesis; ${ }^{*} \mathrm{p}<0.05,{ }^{* *} \mathrm{p}<0.01,{ }^{* * *} \mathrm{p}<0.001$

The strongest models are these explaining attitudes towards the items 'civil servants are more corrupt than normal people' and 'politicians are more corrupt than normal people'. Opinions about political corruption are strongly influenced by party preference. Extreme right voters are more likely to think that politicians are more corrupt than other people. Just eight percent of the extreme right voters disagree with the statement that politicians are more corrupt than normal people. Social-democrats and liberals are less likely to think politicians are more corrupt than other individuals. At the time of data collection, these were the two main 
parties in the regional and federal governments, but an alternative explanation could be that certain traditional voter segments of these parties have defected rather early to the extreme right. Respondents with individualistic attitudes are more likely to label politicians as corrupt, as is a lower education, and a propensity to watch the TV news on a commercial TV channel, rather than on public TV.

Perceptions of administrative corruption tend to be influenced by being female, lower educated, scoring higher on individualism, and a somewhat higher authoritarian attitude. As is the case for perceptions of political corruption, a party preference for the extreme right leads to a higher perceived corruption. Voting for Christian-democrats leads to lower perceived administrative corruption. Despite the number of explanatory variables, the models for political and administrative corruption explain just 14.3 and 14.8 per cent of total variation.

The models for equal treatment and for getting what one is entitled to have very low R squares, yet there are a number of significant relationships. Stronger authoritarian attitudes co-exist with stronger beliefs in equal treatment. Individualism leads to a higher belief that everyone will in the end get what they're entitled to when interacting with public services; Perceptions and expectations of equal treatment are higher among supporters of the social-democratic party, a party whose ideology stresses equality. There are some effects of education and gender: females and lower educated persons are somewhat more inclined to believe that public service users will get that to which they are entitled.

Christian-democrats, Greens, and Social-democrats are less inclined to believe connections are needed to get something done, while individualism and a lower education leads to a higher perceived need of connections, just as does being female. Those reading reputable newspapers do not agree that connections are needed. Overall, again, the model's explanatory power is quite low.

When we only look at the three models directly dealing with corruption (administrative and political, and the perception that connections are needed), a 
lower education, high individualism, and a preference for the extreme right are important determinants. All these variables are frequently encountered in the research on political alienation. It is thus likely that, instead of reflecting opinions on or experiences with corruption, the dependent variables could in fact be considered as expressions of this alienation. Stating that connections are needed, or that civil servants are corrupt may therefore be the result of actual experienced corruption, but it may also be part of a general (negative) predisposition towards government. We expand our model, to include a number of political alienation variables. All alienation variables load on a single factor:

- Voting is useless; the parties do what they want to do anyway

- Most politicians promise a lot, but don’t do anything

- Most of our politicians are competent people, who know what they are doing

- Parliament can best be abolished, since it does not solve any problem

- The present political system is rotten

- To what extent do you trust government?

All variables have been recoded from five to three categories. Because media exposure was not relevant in the basic model, we drop it here.

Table 5: The effects of political alienation on corruption, ordinal regression models

\begin{tabular}{|c|c|c|c|}
\hline & $\begin{array}{l}\text { Civil servants } \\
\text { corrupt }\end{array}$ & $\begin{array}{l}\text { Politicians } \\
\text { corrupt }\end{array}$ & $\begin{array}{l}\text { Need } \\
\text { connections }\end{array}$ \\
\hline \multirow{2}{*}{$\begin{array}{l}\text { SEX } \\
1=\text { female })\end{array}$} & $0.233^{* *}$ & 0.108 & $0.244 * *$ \\
\hline & $(0.074)$ & $(0.078)$ & (0.079) \\
\hline \multirow[t]{2}{*}{ EDUCATION } & $-0.108 * *$ & $\begin{array}{l}-0.025 \\
\end{array}$ & $-0.072 *$ \\
\hline & $(0.031)$ & $(0.033)$ & $(0.032)$ \\
\hline AGE & -0.049 & -0.035 & $-0.061 *$ \\
\hline
\end{tabular}




\begin{tabular}{|c|c|c|c|}
\hline & $(0.027)$ & $(0.028)$ & $(0.029)$ \\
\hline \multirow[t]{2}{*}{ AUTHORITARIANISM } & $0.044 * *$ & 0.012 & $0.041^{* *}$ \\
\hline & $(0.014)$ & $(0.015)$ & $(0.015)$ \\
\hline \multirow[t]{2}{*}{ INDIVIDUALISM } & $0.116 * * *$ & $0.078 * * *$ & $0.041^{* *}$ \\
\hline & $(0.015)$ & $(0.015)$ & $(0.016)$ \\
\hline \multirow[t]{2}{*}{ PARTY: agalev } & 0.400 & $0.621 *$ & -0.156 \\
\hline & $(0.232)$ & $(0.241)$ & $(0.231)$ \\
\hline \multirow{2}{*}{ PARTY: cd\&v } & -0.112 & 0.055 & -0.088 \\
\hline & $(0.132)$ & $(0.139)$ & $(0.141)$ \\
\hline \multirow{2}{*}{ PARTY: n-va } & 0.029 & 0.244 & 0.140 \\
\hline & $(0.215)$ & $(0.224)$ & $(0.225)$ \\
\hline \multirow[t]{2}{*}{ PARTY: sp-a } & $0.322 *$ & $0.302^{*}$ & 0.124 \\
\hline & $(0.134)$ & $(0.141)$ & $(0.143)$ \\
\hline \multirow[t]{2}{*}{ PARTY: spirit } & $0.726 * *$ & 0.359 & $0.547 *$ \\
\hline & $(0.214)$ & $(0.228)$ & $(0.244)$ \\
\hline \multirow[t]{2}{*}{ PARTY: vlaams blok } & 0.238 & 0.283 & 0.001 \\
\hline & $(0.142)$ & $(0.158)$ & $(0.161)$ \\
\hline \multirow[t]{2}{*}{ PARTY: vld } & $0.329 *$ & 0.090 & 0.301* \\
\hline & $(0.131)$ & $(0.138)$ & $(0.141)$ \\
\hline \multirow[t]{2}{*}{ VOTING USELESS } & 0.093 & $0.207 * * *$ & $0.146 *$ \\
\hline & $(0.051)$ & $(0.053)$ & $(0.054)$ \\
\hline \multirow{3}{*}{$\begin{array}{l}\text { POLITICIANS } \\
\text { PROMISE }\end{array}$} & $0.205 * *$ & $0.894^{* * *}$ & $0.264 * * *$ \\
\hline & & & $(0065)$ \\
\hline & $(0.066)$ & (0.068) & (0.065) \\
\hline \multirow[t]{2}{*}{ COMPETENT } & $-0.226 * * *$ & $-0.426 * * *$ & -0.120 \\
\hline & $(0.056)$ & $(0.060)$ & $(0.061)$ \\
\hline \multirow[t]{2}{*}{ ABOLISH PARL. } & $0.344 * * *$ & $0.255^{* * *}$ & $0.250 * * * *$ \\
\hline & $(0.058)$ & $(0.063)$ & $(0.065)$ \\
\hline \multirow[t]{2}{*}{ SYST. ROTTEN } & $0.245^{* * *}$ & $0.595 * * *$ & $0.404 * * *$ \\
\hline & $(0.062)$ & $(0.064)$ & $(0.065)$ \\
\hline \multirow[t]{2}{*}{ TRUSTGOV } & $-0.512 * * *$ & $-0.347 * * *$ & $-0.607 * * *$ \\
\hline & $(0.069)$ & $(0.071)$ & $(0.071)$ \\
\hline $\mathrm{N}$ & 2840 & 2852 & 2842 \\
\hline Nagelkerke pseudo R² & .256 & .421 & .238 \\
\hline
\end{tabular}




\begin{tabular}{|l|l|l|l|}
\hline $\mathrm{R}^{2}$ increase $^{\mathrm{a}}$ & .118 & .286 & .149 \\
\hline
\end{tabular}

${ }^{a}$ increase compared to basic model without media variables; Note: standard errors in parenthesis; ${ }^{*} \mathrm{p}<0.05,{ }^{* *} \mathrm{p}<0.01,{ }^{* * *} \mathrm{p}<0.001$

In all three cases, almost all alienation variables are significant determinants for the corruption and ethics perceptions. In one of the two cases where relationships are not significant at the $\mathrm{p}<0.05$ level, there is border significance. Adding the alienation variables leads to a substantial and even sometimes very substantial increase in explained variance $\left(\mathrm{R}^{2}\right)$. Together with some party preference variables, alienation accounts for most of the variance in the corruption and ethics perceptions. The impact of extreme right voting, which was relevant in the basic models, disappears, possibly due to the fact that this voting behavior is partly determined by alienation.

\section{What about causality?}

The classical, mechanistic explanation for this kind of findings is that citizens feel alienated from their political or administrative system because they perceive it as being corrupt. In this chapter however, we defend the hypothesis that perceptions of corruption are in fact expressions of a more general attitude towards government. A further implication of this viewpoint is that the attitudes as measured in our survey cannot be considered as adequate reflections of actual corrupt practices. We briefly return to this second point towards the end of the chapter.

In previous research on citizens' perceptions of public services and on citizens' trust in institutions we have shown that there is a substantial degree of generalization in respondents' answers to quite general questions (Van de Walle, 2004c). Trust in a certain institution quite often coincides with trust in most 
institutions. Dissatisfaction with government in general often coincides with dissatisfaction with a broad range of issues. A person with a negative attitude towards government is also more likely to complain about high taxes, corruption, or administrative inefficiency. Certain general predispositions towards government influence most attitudes towards government-related aspects.

This has important implications for the interpretation of survey findings like the ones we have presented above, and for building explanatory models. Failing to recognize this generalization of negative or positive attitudes towards government often results in models that are very good at proving that what one wanted to prove in the first place. Correlations between general negative attitude towards government and more specific elements of dissatisfaction (taxes, corruption ...) do not necessarily mean that high taxes or high levels of perceived corruption are to be seen as causes of or explanations for this dissatisfaction. Instead, these specific elements could be interpreted as expressions of this general attitude. It would thus be premature to look at the models in Table 5 and to consider citizens' political alienation as resulting from high levels of corruption. Instead, perceived corruption and perceived unethical behavior are an expression of this political alienation. By presenting the perceptions of corruption and unethical behavior as dependent variables, we have further illustrated our point.

Proving causality, however, is not common in social methodology, and often is simply impossible. Yet, causal constructions are an important rhetorical device. Hence Ruscio's criticism on the all-too-easy prescriptions for restoring citizens' trust in government:

Reactions to the decline (of trust, svdw) have certainly not been lacking, but they typically follow a predictable formula: an analyst's alarmed response which is used to justify a set of prescriptions favored by the analyst. Trust can be restored by - take your pick - term limits, balanced 
budgets, regulatory reform, reinventing government, campaign reform, responsible journalism, stronger political parties, a third political party, vigorous state and local government, constraints on lobbying or an end to divided government (Ruscio, 1997: 454).

Limiting corruption and the introduction of an ethics infrastructure could easily be added to this list.

\section{Do general perceptions reflect personal experience?}

For citizens, it is not easy to base their perceptions about or attitude towards corruption on personal experience. Fragmented evidence suggests that actual individual acts of corruption are quite limited in most Western countries. In the International Crime Victims Survey for instance, a question is included on actual experienced corruption in relations with, for example customs officers, police officers and inspectors or other government officials ${ }^{4}$. Frequencies for these items are generally low to extremely low (Van Kesteren, Mayhew, \& Nieuwbeerta, 2000). In our own survey, we included an item on politicians' constituency service and the extent to which citizens have approached a politician during the last four years for solving a personal problem ${ }^{5}$. Just 2.5 percent of respondents mentioned

\footnotetext{
${ }^{4}$ Q290: 'In some countries, there is a problem of corruption among government of public officials. During 1999, has any government official, for instance a customs officer, a police officer or inspector in your country asked you, or expected you to pay a bribe or his or her services?' Answer = yes/no. In Belgium there were 9 'yes' answers on 2501 respondents in the 1999 survey.

5 'People sometimes call on politicians for solving personal problems. Did you during the last four year call on a politician's constituency service for solving some
} 
more than one contact, while 9.6 percent of respondents admitted having approached a politician in the four preceding years. Using politicians' constituency service does of course not equal corruption. Other methods frequently used to measure actual corruption rather than perceptions are household surveys, where personal stories of corrupt experiences are shared and recorded within specific groups. The method is less often used in developed countries, probably because of the lower occurrence of corrupt acts, and costs of collecting meaningful data.

Absence of personal experience forces survey respondents in general surveys to relate to other elements or information to form their opinion on corruption. The number of respondents whose answers are related to corruption based on recently experienced corruption is likely to be extremely low. Reactions to a statement such as 'you need connections to get something done from government' do not necessarily have a specific referential basis, but more probably refer to information

personal problem?' We use the Dutch word 'dienstbetoon', which is generally translated as constituency services, but which is in fact something more specific. 'Dienstbetoon' refers to the waning Belgian politicians' habit for holding office every week or month somewhere in their constituency to meet individual citizens. Traditionally, this practice has been associated with corruption, for example because citizens visited politicians to arrange jobs for family members or to get building permits. Nowadays, however, the practice has evolved into some kind of front-office social work, where politicians are considered easier to approach than are certain national administrations. Politicians are now believed to limit their 'dienstbetoon' to showing citizens the correct administration they should contact with a certain problem or to referring citizens to the ombudsman. Of the respondents in our survey who had approached a politician, 33.9 per cent stated it helped solving the problem, while 49.9 per cent declared it did not. The others (29.9 per cent) took a neutral position. 
about government in general that is present in the respondent's mind (Zaller, 1996). Most probably this information concurs with general attitudes towards government and with the general stereotypes of government and administrations (Van de Walle, 2004a).

Here, a parallel with research on citizens' perception of public services surfaces. For several decades, scholars have repeatedly stumbled on a number of apparent contradictions in citizens' opinion about public services. One contradiction deals with process. Citizens dislike inefficiency but are equally dissatisfied when delivery of services is ruthlessly efficient (Blau, 1956:14). Citizens complain about cumbersome red tape and paper-based interaction, but wouldn't like either that the official would forget precious details about the specific encounter (du Gay, 2000). Both vices and virtues of bureaucratic systems are used to fuel the traditional dislike of the bureaucracy (Hill, 1992): corruption itself as well as the bureaucratic impersonality that results from anti-corruption measures may give rise to dissatisfaction. An inefficient police force creates dissatisfaction, but so does a police force that is too eager issuing parking tickets. Two dominant images prevail: the lazy, incompetent bureaucrat vs. the power-hungry, manipulative civil servant. It is not quite obvious how these two images may reasonably co-exist.

The other contradiction, perhaps more important here, deals with evaluation. While many citizens dislike the public administration in general, they are actually quite satisfied with many concrete services. Citizens generally evaluate specific and concrete services in a more positive way than is the case for government in general or for general concepts such as 'the public administration.' The general image of the bureaucracy does not correspond to the evaluation citizens make about their own experience with public services ('bureaucratic encounters'). Public administration scholars started to write about this in the 1970s. One of the earliest extensive studies on the issue was a large-scale study by Katz et al. (1977) on 
differences in the evaluation of public and private services. They asked respondents to evaluate public and private sector services in general, as well as a recently used public and private sector service. When respondents had to compare public and private sector services, they indeed rated private sector services higher. However, when the comparison concerned the private and public sector service that was used most recently, differences between the evaluation of public and private sector services disappeared. Goodsell devoted an entire book (The Case for Bureaucracy 1983) to the issue of divergence between evaluations of concrete bureaucratic encounters and the general public attitude vis-à-vis the bureaucracy. Most of Goodsell's observations are echoed in other research and articles as well (Grunow, 1981), and his theoretical explanations do not differ greatly from Katz et al.'s research on bureaucratic encounters. Klages (1981) referred to German research indicating differences in citizens' evaluation of civil servants in general and employees who provide specific public services. Hill (1992: 20), in his chapter entitled Taking bureaucracy seriously wants to know why citizens state they were treated fairly by the administration, while they don't think governmental offices are giving fair treatment. Although Hill uses some new survey material, his approach does not introduce much more than Goodsell. Hill's evidence found that citizens tend to agree with negative statements about the bureaucracy when these are unrelated to bureaucratic performance and vague enough to serve as an outlet for the stereotypical anti-bureaucratic images (Hill, 1992: 22). The explanation lies therefore not in the degree of generalizations, as can be concluded from reading Goodsell, but rather on the symbolic content of concepts and objects and not on the level of abstraction: 'The conventional wisdom in political science and social psychology has been that abstract attitude objects are processed differently than concrete ones. The simple symbolic politics view assumes that processing of political symbols depends on the evaluations associated with them, not on the symbol's level of abstraction' (Sears, 2001: 20). The abstract objects studied in 
public administration (government, bureaucracy, civil servants) often bear negative symbolic content, and this content is being reflected when respondents are asked to give an opinion on the administration or bureaucratic ethics and corruption. Because of the high level of abstraction of the concept (public administration) or the low level of personal experience (corruption), respondents form an answer that is plausible because it is compatible with the general symbolic content and their own general attitude towards government.

\section{What about perceptions of corruption?}

How do we find these processes in perceptions of corruption? In our WADO survey, we also asked respondents to indicate their level of trust in a series of institutions ( $1=$ very little; $5=\mathrm{a}$ lot). At the beginning of the questionnaire, a general item on trust in government was also included ${ }^{6}$. Table 6 shows how the general opinion on corruption correlates quite strongly with trust in government in general and with trust in more general and diffuse institutions, while correlations with rather specific institutions are considerably weaker. The correlation between perceptions of corruption and general trust in government is the highest, directly followed by the quite generally phrased items such trust in the Flemish administration, Federal administration and municipal administration. At the bottom of the list are very specific services such as the railway company, the postal service etc., where correlations are very small, yet still significant. A traditional explanation would be that citizens tend to associate institutions such as the Flemish or Federal administration more with corruption than is the case for services such as the postal service or the national railways.

\footnotetext{
${ }^{6}$ General question near the start of the survey: 'To what extent do you trust government' (1-5 scale)
} 
Table 6: Trust and corruption: correlations

\begin{tabular}{|c|c|c|c|}
\hline \multicolumn{4}{|c|}{ You need connections to get something done } \\
\hline Trust & $\begin{array}{l}\text { Correlation } \\
\text { Coefficient }\end{array}$ & Trust & $\begin{array}{l}\text { Correlation } \\
\text { Coefficient }\end{array}$ \\
\hline Government (general) & -0.31 & $\begin{array}{l}\text { European } \\
\text { Commission }\end{array}$ & -0.17 \\
\hline Flemish administration & -0.26 & Police & -0.17 \\
\hline Federal administration & -0.25 & Courts/justice system & -0.15 \\
\hline $\begin{array}{l}\text { Municipal } \\
\text { administration }\end{array}$ & -0.23 & Educational system & -0.12 \\
\hline Flemish Parliament & -0.20 & $\begin{array}{l}\text { Public transport (bus, } \\
\text { tram) }\end{array}$ & -0.11 \\
\hline Flemish Government & -0.20 & $\begin{array}{l}\text { Flemish employment } \\
\text { agency }\end{array}$ & -0.10 \\
\hline Belgian Parliament & -0.20 & Public television & -0.10 \\
\hline Belgian Government & -0.20 & Refuse collection & -0.08 \\
\hline $\begin{array}{l}\text { Flemish political } \\
\text { parties }\end{array}$ & -0.18 & Army & -0.06 \\
\hline $\begin{array}{l}\text { Walloon political } \\
\text { parties }\end{array}$ & -0.18 & Postal service & -0.06 \\
\hline $\begin{array}{l}\text { College of mayor and } \\
\text { aldermen }\end{array}$ & -0.17 & Railway company & -0.05 \\
\hline
\end{tabular}

Source: Werken aan de Overheid (WADO) 2003, n=3168, Kendall's Tau b, all correlations significant.

It would be incorrect however to infer from these findings that citizens experience or have experienced more frequent occurrences of corruption in these non-specific institutions ('the administration', 'government'). In fact, these correlations merely confirm what we have described earlier. Even though we have not measured perceptions of corruption in very specific and concrete governmental institutions, we can quite confidently state that survey respondents will report lower corruption in many specific institutions than they will for the public administration or government in general. Exceptions to this 'general rule' will then 
probably be services where there have recently been corruption scandals or services that traditionally had a very negative image. This means that the opinion on corruption is probably part of a general opinion about government and not so much the result of actual experience. General surveys do not distinguish whether these opinions are part of the general attitude towards government or resultant from actual experienced corruption.

The relationship between general opinions about corruption, and general attitudes towards government are also visible in a more international analysis. Figure 3 shows the levels of confidence in the civil service in the EU countries (excluding Malta and Cyprus), as measured in the European Values Study, and these countries' scores on the Transparency International Corruption Perceptions Index in the same year. Even though imperfect, there is a strong correlation between both indicators (Pearson correlation $=.506)$.

Figure 3: Confidence in the civil service and perceptions of corruption

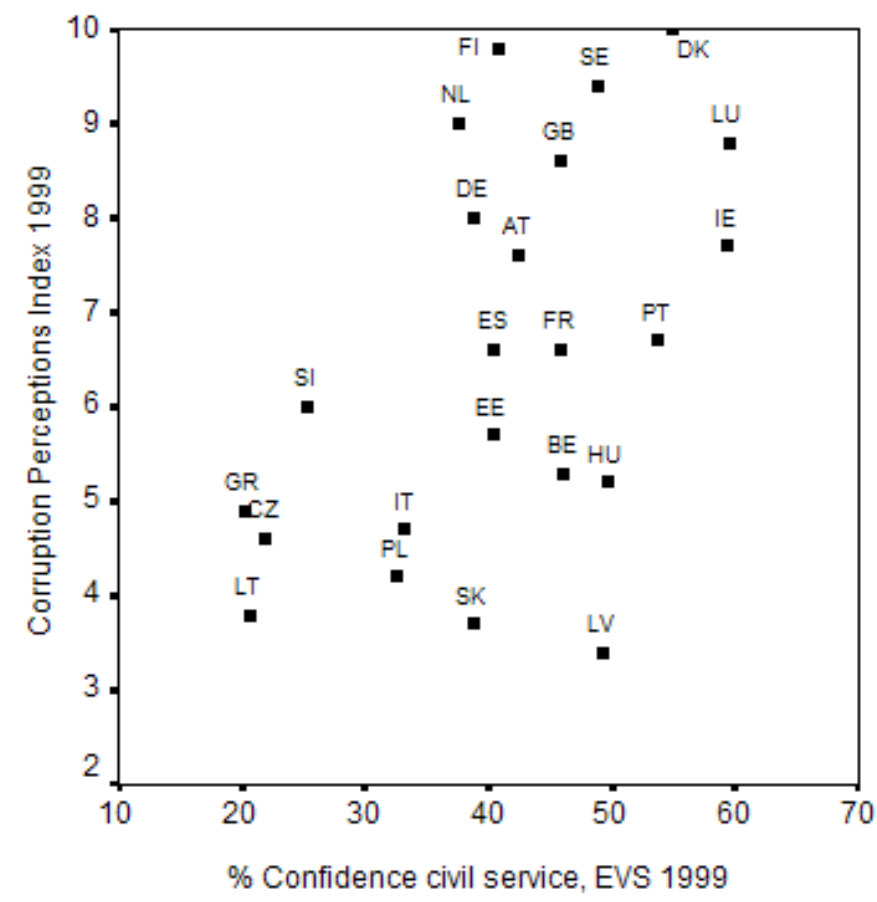

Source: Transparency International Corruption Perceptions Index 1999 and European Values Study 1999: \% 'a great deal' and 'quite a lot' of confidence. 
Again, this figure may be seen as indicating that corruption drives down confidence in the civil service, but it can also be interpreted as supporting our view that both perceptions of corruption, and confidence in the civil service, are derived from a general view of government. There are no reliable criteria however, to decide whether and when a corruption perception indicator reflects generalized views of government or actual experience with corruption.

\section{A need for better measurement of corruption?}

While perceptions of corruption as a factor of general attitudes toward government are an interesting indicator for researchers, most practitioners and policy-makers are interested in actual corruption. This chapter clearly showed that general items on perceived corruption risk to be 'contaminated' by general predispositions towards government. Generally, there are two possibilities for isolating citizens' perceptions of corruption from general predispositions toward government. One is to avoid broad and general questions and instead to focus on specific and concrete situations. The other is to do away with measuring perceptions altogether and to step up efforts to develop objective indicators of corruption.

\section{Specific measurement}

We have shown that general perceptions of corruption correlate with levels of trust in quite general institutions. The more specific an item in a questionnaire, the narrower the respondent's framework of reference for answering the question becomes. This may help in filtering predispositions. A general question such as 'is the public administration corrupt' invites respondents not only to think about recent experience, but also to think about all possible administrations, about bureaucratic stereotypes, even about politicians, etc. A more narrowly defined question such as 'did you personally experience corruption in service $\mathrm{Y}$ during the past three 
encounters' drastically confines the framework of reference to service $\mathrm{Y}$ and helps to exclude many of the general predispositions towards government or administrations. Specific measurement of corruption should therefore disaggregate the general corruption items and ask questions on corruption with regard to many different specific services and with regard to many different expressions of corruption. Some examples are the Transparency International Global Corruption Barometer, where respondents were asked to give their opinion on the presence of corruption in a series of sectors. They also could indicate the amount of bribes paid by one's household, and the reason why this was done (www.transparency.org). The barometer did not, however, link actual behavior to specific sectors. Even more detailed are household surveys, some also conducted by Transparency International. In these surveys, detailed questions about corrupt practices and experiences are included. These questions refer to concrete interactions with government services and officials. For policy makers such a specific measurement is also important, because it shows them where and how corruption is manifest and hence facilitates action. Policymakers who use general corruption indicators can in fact only use this information to decide on general measures to combat corruption, without being able to establish priorities for action. Most of these very detailed surveys are conducted in developing countries. Lower occurrence of corrupt practices in developed countries would require very large samples to gather significant data, thus rendering them somewhat more impractical.

\section{Objective measurement}

Possibilities for measuring corruption objectively are sparsely reported in the literature. One approach counts the number of cases related to corruption before the courts. In Belgium, Yante (2003) analyzed the number of lawsuits related to corruption. Despite the often-defective judicial statistics, he did find a decrease and also observed a tendency for more severe punishment in corruption cases. This 
relatively easy approach negates certain aspects, because corruption is essentially an illegal and hidden activity (Kaufmann, Kraay, \& Mastruzzi, 2003). A falling number of lawsuits may also suggest decreasing judicial oversight or more hidden corruption. Essentially, effectively measuring corruption is de facto combating corruption.

Kaufmann et al., in their Governance Matters III working paper, refer to a small number of studies that attempted to measure corruption directly. They mention Di Tella and Shargrodsky (2003), who measure variation in procurement prices for medical supplies, where high variation suggests there is corruption involved, and Golden and Picci (2005), who compare expenditures for public infrastructure with existing inventories, where high discrepancies may hint at corruption.

A third approach is to map incentives and opportunities for corruption (RoseAckerman, 1999), influenced by the demand and supply in the citizen-official encounter. Opportunities for asking or giving bribes may be influenced by the level of discretion exercised by the civil servant or political decision-makers. Incentives are influenced by factors such as the likelihood of being caught, and the savings in time and money to be had by circumventing customary procedures, especially when the customary procedure is long and expensive with unpredictable outcomes.

\section{Conclusion}

In this chapter, we analyzed determinants of subjective perceptions of corruption in Belgium. Belgium, a country with a somewhat corrupt image, seems to have made some progress in dispelling such negative perceptions during the last decade, as demonstrated by the country’s Transparency International rankings. In an analysis of survey data, we found political alienation to be one of the main determinants of citizens' perception of political and public sector corruption and of unethical 
behavior in the administration. This had important implications for both the interpretation of the causal link between corruption and other attitudes towards government, and for the practice of measuring corruption. General surveys revealed that opinions on corruption and unethical behavior are embedded in more general attitudes toward government. Unlike the reportedly widespread personal experience with public corruption in Belgium, citizens of Western countries hear about corruption but research has demonstrated that firsthand experiences remain limited, thus emphasizing the geographical and cultural limitations of this study.

Still, general perceptions of corruption are often used as measures of corruption in a country. These general perceptions are useful indicators for attitudinal research, and also have a value in mapping a country’s image. There is a need however for the development of more objective indicators of corruption, and when surveys are used, very specific questions are to be asked, rather than general queries. Finally, because perceptions of corruption seem to be an expression of general attitudes towards government, we can no longer simply use surveys to prove that low levels of trust are a consequence of corruption. Rather, high levels of perceived corruption are probably a reflection of low trust. An implication of this is that declines in actual corruption will not immediately have an impact on citizens' general perceptions of the occurrence of corruption.

\section{References}

Beerten, Roeland, Jaak Billiet, Ann Carton and Marc Swyngedouw (1997), 1995 General Election Study Flanders-Belgium: Codebook and Questionnaire, Leuven: ISPO.

Blau, Peter. M. (1956), Bureaucracy in Modern Society. New York: Random House. 
De Winter, Lieven (2000), 'Political Corruption in the Belgian partitocracy: (still) an endemic disease?’, EUI working paper RSC No. 2000/31.

De Winter, Lieven (2003), 'Political Corruption in Belgium', in Martin J. Bull and James L. Newell (eds.), Corruption in contemporary politics, Houndsmills: Palgrave Macmillan. pp. 93-105.

du Gay, Paul (2000), In Praise of Bureaucracy. London: Sage.

Golden, Miriam and Lucio Picci (2005), 'Proposal for a New Measure of Corruption, and Tests Using Italian Data’, Economics and Politics, 17 (1), 3775.

Di Tella, R. and E. Shargrodsky (2003), 'The Role of Wages and Auditing During a Crackdown on Corruption in the City of Buenos Aires', Journal of Law and Economics, 46 (1), 269-292.

Goodsell, Charles T. (1983), The Case for Bureaucracy: A Public Administration Polemic, Chatham: Chatham House Publishers Inc.

Grunow, Dieter (1981), 'Client-Centered Research in Europe', in Charles T. Goodsell (ed.), The Public Encounter: Where State and Citizen Meet, Bloomington: Indiana University Press, pp. 223-41.

Halman, Loek (2001), The European Values Study: A Third Wave Source Book of the 1999-2000 European Values Study Surveys, Tilburg: WORC, Tilburg University.

Hill, Larry B. (1992), ‘Taking Bureaucracy Seriously’ in Larry B. Hill (ed.), The State of Public Bureaucracy, Armonk, New York: M. E. Sharpe, pp. 15-57.

Katz, Daniel, Barbara A. Gutek, Robert L. Kahn and Eugenia Barton (1977), Bureaucratic Encounters: A Pilot Study in the Evaluation of Government Services, Ann Arbor: Institute for Social Research.

Kaufmann, Daniel, Aart Kraay and Massimo Mastruzzi (2003), Governance Matters III: Governance Indicators for 1996-2002, Washington, D.C.: World Bank. 
Klages, Helmut (1981), 'Das Verhältnis zwischen Staat und Bürgern in der Bundesrepublik Deutschland', in Michael Buse and Horst Burschmann (eds), Bürgernahe Verwaltung und der Verwaltungsausbildung, Baden-Baden: Nomos Verlaggesellschaft, pp. 24-43.

Maesschalck, Jeroen (2002), 'When do Scandals have an Impact on Policy Making? A Case Study of the Police Reform Following the Dutroux Scandal in Belgium’ International Public Management Journal, 5 (2), 169-193.

Rose-Ackerman, Susan (1999), Corruption and Government: Causes, Consequences, and Reform. Cambridge: Cambridge University Press.

Ruscio, Kenneth P. (1997), 'Trust in the Administrative State (book review)', Public Administration Review, 57 (5), 454-458.

Sears, David O. (2001), 'The Role of Affect in Symbolic Politics', in James H. Kuklinski (ed.), Citizens and Politics, Cambridge: Cambridge University Press, pp. 14-40.

Van de Walle, S. (2004a), 'Context-Specific Images of the Archetypical Bureaucrat: Persistence and Diffusion of the Bureaucracy Stereotype', Public Voices, 7 (1), 3-12.

Van de Walle, S. (2004b). 'Kan er iets geregeld worden? Corruptie bij de overheid in cijfers', Vlaams Tijdschrift Voor Overheidsmanagement, 9 (4), 39-45.

Van de Walle, Steven (2004c), Perceptions of Administrative Performance: The Key to Trust in Government? Leuven: Instituut voor de Overheid, diss. doct.

Van de Walle, Steven, Jarl K. Kampen, Bart Maddens and Geert Bouckaert (2004),

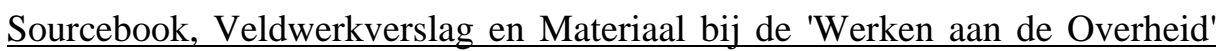
Surveys. Leuven: Instituut voor de Overheid.

Van de Walle, Steven, Jarl K. Kampen and Geert Bouckaert (2005), 'Deep Impact for High Impact Agencies? Assessing the Role of Bureaucratic Encounters in Evaluations of Government', Public Performance and Management Review, 28 (4), 532-549. 
van Kesteren, John, Pat Mayhew and Paul Nieuwbeerta (2000), Criminal Victimisation in Seventeen Industrialised Countries: Key-findings from the 2000 International Crime Victims Survey, The Hague: Ministry of Justice, WODC.

Yante, J.-M. (2003), 'La Corruption dans l'Administration belge aux XIXe et XXe Siècles' in Seppo Tiihonen (ed.), The History of Corruption in Central Government, Amsterdam: IOS Press. pp. 65-82.

Zaller, John (1996), The Nature and Origins of Mass Opinion, Cambridge: Cambridge University Press. 